\title{
THE ANALYSIS OF POSSIBILITIES AND LIMITS OF INTENSIFICATION OF INTERNATIONAL COOPERATION OF REGIONS
}

\author{
Lyudmila Kutidze \\ Department of Management \\ Zaporizhzhya National Technical University \\ 64 Zhukovskogo str., Zaporizhzhya, Ukraine, 69063 \\ kutidze@mail.ru
}

\begin{abstract}
The factors of international environment that influence international cooperation of the regions of Ukraine are considered in the article and it was revealed, that the possibilities of its intensification are given by the development of new organizational forms of cooperation.

International activity of regions is realized within their authorities taking into account coordinating role of the national bodies of power. That is why the analysis of limitations that impedes the full use of possibilities of international cooperation due to the use of its diverse forms needs the complex consideration of factors of the national and regional environment.

Institutional, financial, organizational limitations of intensification of international cooperation of the regions of Ukraine were determined. It was proved, that the main limitation is organizational factors, especially: absence of coordination between the departments that are responsible at the national level for realization of the programs of international cooperation of regions; absence of the mechanisms of interaction between state and regional authorities, public and business representatives; insufficient informational support of concerned parties.

The solution of the problem of intensification of international cooperation between the regions needs the complex approach to organization of interterritorial cooperation and elaboration of transparent mechanisms that would combine the efforts of participants of the process of solving problems of institutional, organizational, financial support of international cooperation.

Realization of such approach is connected with the necessity of institutional formation of rules, authorities, responsibilities of the power bodies of the different levels, establishing of communicational channels. It needs the use of mechanisms of strategic and program-objective management of activity. It is expedient to create the regional programs of international interaction that would determine the competitive advantages, priority branches, possibilities and resources of their development with orientation on the strengthening of competitiveness of every region.
\end{abstract}

Keywords: international cooperation between regions, forms of international cooperation, possibilities and limitations of international cooperation of regions, mechanisms of coordination and interaction.

\section{Introduction}

The growth of significance of the state regions in the system of international relations is the one of tendencies that determines the character of world development at the modern stage. And integration processes condition the necessity to involve the regions of Ukraine into the system of international cooperation that is especially actual in the conditions of economic instability in the country. The one of mechanisms of economic activity of the subjects of regional economy that favors the development of innovative processes, involvement of investments, formation of the centers of economic growth is the use of potential of international cooperation between regions.

\section{Analysis of the literary sources and statement of problem}

Scientists pay significant attention to the problems of globalization and regionalization, their influence on the development of international connections between regions. In the works [1, 2] the fundamental problems of regional development and regional policy are presented. The features of territory development, caused by the processes of globalization are considered in the work [3]. The study [4] is devoted to the problems of transnational connections and decentralized cooperation between regions. The experience of European international cooperation and elaboration of processes of the regional management is analyzed in [5, 6]. In the work [7] the special attention was paid to the prospects of regionalism in Eastern Europe. 
The problems of international interaction between regions attract the significant attention of the native scientists in theoretical and applied aspects. The experience of activity of transboundary association of Western European countries is presented in the work [8]. Methodological aspects of interregional and transboundary cooperation and formation of international cooperation system in Ukraine are considered in scientific publication [9]. Theoretical-methodological, organizational-legal and practical aspects of formation of international cooperation between territories are elucidated in the monograph [10]. Scientists pay the significant attention to the analysis of the regulatory and legal support of international connections between regions [11], and also to institutional support of transboundary cooperation [12]. Practical recommendations as to the development of international regional cooperation of the regions of Ukraine are given in scientific-analytic reports [13, 14]. But the transience of the external environment factors conditions the permanent need in revelation of the new possibilities of international cooperation and analysis of the necessary conditions for their effective use in Ukraine.

\section{Aim and tasks of research}

The aim of research is determination of possibilities of intensification of international cooperation of Ukrainian regions and analysis of limitations of their full use.

For attaining this aim the following tasks were set:

1. To analyze the possibilities of intensification of international cooperation of Ukrainian regions.

2. To reveal limitations which impede the full use of these possibilities.

3. To determine the possible directions of overcoming limitations for the most effective use of potential of international cooperation of regions.

\section{Materials and methods of research}

The main method of the study of international cooperation of regions in the article is a situational analysis on the base of SWOT - analysis that is used for assessment of correspondence of strategic choice to the factors of internal and external environment. The principles of SWOT - analysis methodology are presented in the work [15], and its use for planning the regional development in materials [16].

\section{Results of research}

It is necessary to consider international cooperation as the one of strategic dominants of the development of economic potential of regions that gives impulse to the establishment of international interaction between the subjects of economy, development of infrastructural and innovative support of regional economy. Scientists defines international cooperation as a "common action of the regional bodies of state administration, local authorities, participants of economic relations and territorial communities of Ukraine and, possibly, also the correspondent power bodies of other countries, directed on establishment and deepening of economic, social, scientific-technical, ecological and other relations aimed at making any necessary arrangement or attaining agreements" [17]. That is, when such mutually agreed activity takes place between the power bodies of two or several regions of the different states, we can talk about international cooperation of regions.

International cooperation of regions has diverse legal bases, different organizational structures and geographic directionality. Thus, for example, international cooperation of regions can be realized as transboundary and interterritorial one.

Transboundary cooperation it is "any common actions, directed on strengthening and deepening of the good-neighborly relations between the territorial communities or powers that are under jurisdiction of two or several contracting parties and also making any necessary arrangement or attaining agreements, aimed at that" [18].

"Interterritorial cooperation means any mutually agreed activity, directed on initiating relations between the territorial communities and powers of two or more contracting parties that besides the relations of transboundary coordination between the neighboring power bodies includes making agreements on cooperation between the territorial communities and power bodies of other countries [19]. 
Thus, interterritorial cooperation determines the rule of territorial power body of any level to cooperate with correspondent territorial power bodies of other states. The term "interregional cooperation" for Ukraine can outline the legal frames of territories that occupy the second level after the central one (for Ukraine they are regions) [10].

Political-legal, economic, socio-cultural factors of international environment must be considered as the ones that give possibilities of intensification of international cooperation of regions. Generalization of the studies in this direction indicates that in the legal plane the main obstacles for the development of international connections between regions are the differences in the legal status of cooperating regions and also the lack of the legal base of international connections between regions. The excessive political control of the national instances acts as political obstacle. The socio-cultural barriers are language differences, certain negative stereotypes. To the difficulties of social-economic character are related the different levels of development of regions, insufficiently active involvement of private economic actors to international connection of regions, differences in the tax systems of states and so on [11].

But in the last years the institutional base of European interaction of regions develops intensively - the new initiatives are started; the documents that regulate transboundary cooperation are accepted.

Ukraine has the land boundary with seven countries and, correspondingly, the significant possibilities of cooperation with neighboring countries on the projects of transboundary cooperation. Transboundary cooperation is realized within euroregions.

Euroregion it is an organizational form of cooperation of administrative-territorial units of European states that is realized according to two- or many-sided agreements on transboundary cooperation [20]. 10 euroregions were created on the boundaries of Ukraine and neighboring countries. But the strained situation on the Ukrainian-Russian boundary makes impossible the transboundary cooperation with Russia that needs from Eastern regions to activate the work on choice for international partners. For today transboundary cooperation is considered as the factor of realization of EU integration strivings of Ukraine and its state policy is concentrated on this direction.

Institutional support of development of euroregional cooperation between Ukraine and EU permanently increases, its new organizational forms appear, among which are European factions of the territorial cooperation and associations of euroregional cooperations that can function analogously to euroregions but on the different legal bases [21].

European factions of territorial cooperation there are factions, created for facilitation and assistance to the transboundary, transnational and/or interregional cooperation between EU members for strengthening of economic and social unity. They are created mainly for the solution of point tasks or even for the solution of one concrete task.

Associations of euroregional cooperation it is a body of transboundary or interterritorial cooperation between territorial communities or power of two or more states, state or private juridical faces, profitable subjects, created in state-members that act in common social interests, and associations of power bodies that belong to one or more aforesaid categories. Such bodies are created for progress, support and development of cooperation between their members in the spheres of common competence and within authorities, defined by internal legislation of concerned states in the interests of population; they are juridical persons [13].

The regions of Ukraine are the members of international organizations that combine the regions of different countries. The involvement of Ukrainian regions to the activity of European regional organizations, especially, Assembly of European Regions, Council of European municipalities and regions, Conference of European Regional Legislative Assemblies, Association of European Border Regions, Conference of Peripheral Maritime Regions), Conference of President of Regions with legislative power), European Association of elected representatives from Mountain Areas and EUROCITIES are determined by the tasks of the Ministry of international affairs of Ukraine [22].

Scientists note that the important aim of state policy in the sphere of transboundary cooperation must be the fostering to the development of such its forms as transboundary clusters, partnerships, industrial parks, projects, border trade and so on [10, 12, 13]. The grounded analysis of the results of introduction of the new cooperation forms is presented in the work [13]. But most counted forms are not gain the sufficient application and spread in Ukraine yet. 
The other important form of cooperation between countries is the partner and sister connections between the cities. The term "sister connections" is used for definition of the long-term and active relations between two cities in the different spheres of public life, whereas the "partner connections" are mainly limited with cooperation in one or several spheres. The establishment of direct contacts between the regions, cities and districts of Ukraine and the ones of other countries creates the effective mechanism for development of business and public connections and favors the further intensification of strategic partnership. The development of partner and sister connections allows widen geographical limits of international interterritorial cooperation, spreading it on the other directions, besides the traditional partners (Near East, Asian-Pacific region and so on). The establishment of such relations is especially urgent for Ukrainian regions that are not engaged into transboundary cooperation.

Thus, despite the unfavorable political circumstances and economic situation, the development and diversification of organizational forms within European partnership, establishment of sister and partner connections give the possibilities to Ukrainian regions to use the potential of international cooperation more fully.

International activity of the regions is realized within their authorities taking into account coordination of the national power bodies. That is why the analysis of limitation that impede the full use of possibilities of international cooperation due to the use of its diverse forms must be carried out complexly taking into account the factors of national and regional levels.

In first turn there must be analyzed the factors that the state can influence and change to the best. According to the Law of Ukraine "On transboundary interaction", "the function of state is to provide conditions for the use of organizational, financial, institutional possibilities of subjects and participants of transboundary cooperation of Ukraine in elaboration and realization of arrangements as to realization of projects (programs) of transboundary cooperation" [20]. That is why it is expedient to analyze obstacles (weak sides) that impede the full use of the diverse forms of international cooperation of regions, determining institutional, financial, organizational limitations.

Institutional factors. The use of the possibilities of international cooperation by the regions is mainly conditioned by the existent legal base, defined by the regulatory-legal documents that regulate the relations in three planes:

- national legislation that provides the bases of external economic activity;

- legal acts that regulate the relations of central and regional power bodies and management, local authorities in the sphere of international relations;

- international documents and agreements that determine aims, mechanisms and concrete spheres of cooperation with international organizations and the separate foreign countries. "The main volume of regulatory base of international cooperation of regions is formed, their control and coordination in the national scales is provided exactly at the state level" [11].

The regulatory-legal base, according to which Ukrainian regions realize cooperation with the regions of other countries, already is almost created in Ukraine, the series of international agreements as to the development of interregional cooperation are signed. But even for today there are limitations, connected with imperfection of the regulatory-legal support at both state and regional levels. Among the main ones, noted by scientists [10, 12, 17], is the necessity to improve the Law “On technical help", Law “On transboundary cooperation”. Alongside with it the state support of transboundary cooperation must provide the elaboration and realization of the State program of development of transboundary cooperation that is absent for today.

Although the development of institutional support of international cooperation at the regional level is conditioned by the existent legislative base, the following questions are within the responsibility of the regional management bodies and territorial communities:

- inclusion of the plan of actions as to the concrete arrangements in the sphere of international interregional cooperation in the programs of strategic development of the regions;

- addition of the existent agreements on international interaction with the detailed programs of arrangements, plans of actions with determination of authorized bodies and economic subjects that can be involved into its realization and mastering of financial sources and other. 
Financial factors are connected in first turn with the necessity to provide realization of projects of international cooperation. Financing of the projects of transboundary cooperation can be realized at the expense of costs from the national budget, local budgets for correspondent year and also from the other sources, not prohibited by the law. For the common financing of projects and programs of transboundary cooperation the costs of international technical help, credit resources of international financial organizations can be used [23].

The development of forms of interregional cooperation gives Ukrainian regions the possibilities of development of international cooperation at the expense of EU financial instruments. EU program that directly or indirectly concern transboundary cooperation significantly predominates among the other programs of international technical help by the quantity and volume of financing. Thus, among the most active ones as to the financing of the problems of transboundary cooperation in Ukraine can be named [22]:

- programs within "European Instrument of Neighborhood and Partnership (ENPI InterRegional Program). Ukraine has an access to the three programs of transboundary cooperation within ENPI: „Hungry-Slovakia-Romania-Byelorussia” (budget 68,6 mln euro), „UkrainePoland-Byelorussia” (budget 186, 2 mln euro), „Ukraine-Romania- Moldova” (budget 126, 7 mln euro), „Black Sea” (budget 21, 3 mln euro. The aforesaid programs include Volyn, Transcarpathian, IvanoFrankovsk, Odessa, Lviv, Rivne, Ternopil and Chernivtsy regions of Ukraine and also ARC;

- initiative "Eastern partnership". For the strengthening of cooperation between EU regions and the regions of the countries of EU initiative "Eastern partnership" it was accepted the decision as to creation of the Conference of the regional and local authorities for the Eastern Partnership - CORLEAP. The Committee of EU regions (CR EU) favors realization of the diverse programs of the regional cooperation, directed on the strengthening of institutional competence of representatives of the regions of neighboring countries, provides the spreading of information about the socio-economic potential of the regions of EP member-states in Brussels;

- EU strategy for Danube region. The strategy is directed on the support of infrastructural, environmental, socio-economic and institutional development of the region. In geographical aspect the Strategy consists of 14 countries, including Ukraine. The Strategy provides cooperation within 11 priority directions. The financing of realization of projects within strategy can be carried out at the expense of costs within the existent programs of EU technical help and international financial organizations, national budgets.

The main problem in the questions of international cooperation of the native regions is for today the imperfect mechanism of financing of the common projects that are realized at the support of EU programs. It decreases the activity of Ukrainian side in realization of transboundary projects and involvement of financial support from EU structural funds.

The state financing of 10 projects with total volume of financing support 48,3 mln grivnas was provided in Ukraine for the period 2011-2015 for the aims of external interregional cooperation [23]. Most transboundary projects by EU initiative need the involvement of the own financing sources at least at $10 \%$ level. The scientists note that the ones of causes of impossibility to adhere to this parameter is too small volume of authority of the local government, especially as to the budget support of the regional development that complicates the search for the own financing sources [24].

The one of the new instruments of realization of the regional policy in Ukraine is the State Fund of regional development, but the principles of formation and consumption of its costs need renovation. The costs of fund must be directed on realization of investment programs and projects of the regional development (including the projects of regional cooperation), aimed at the development of regions, creation of infrastructure of industrial and innovative parks and so on. But for 2016 the Ministry of Finances of Ukraine allocated 3 bln grivnas for the State fund of regional development that is by 2,28 bln grivnas less that is provided by the budget code [25].

Socio-economic state of the country conditions the restrictive measures as to the financing of regional needs that is why it is possible to increase the income of financial resources for the support of international cooperation at the expense of activation of the own development sources of regions and involvement of extrabudgetary resources. 
Organizational factors. Intensification of international cooperation of Ukrainian regions needs besides the regulatory-legal and financing support the solution of organizational problems that is the distribution of duties, authorities and responsibilities of the participants of process.

Coordination of the arrangements, realized by executive authorities as to the support of the unitary foreign policy course of Ukraine is realized by the Ministry of international affairs of Ukraine. For today the tasks that concern realization of the different forms and instruments of international cooperation of regions are entrusted to the different state bodies. Thus, the general coordination of the work on the programs within "European Instrument of Neighborhood and Partnership" is realized by the Ministry of economic development and trade; the national coordinator of activity on EU Strategy for Danube region is the Ministry of regional development, building and housing complex of Ukraine. The support of the practical cooperation between Ukraine and CORLEAP is realized by the Ukrainian associations of district and regional councils.

The solution of problems and determination of prospects of interregional cooperation taking into account diversification of its organizational forms need coordination of activity of ministries, departments, regional and local authorities. That is why to increase the effectiveness of euroregional cooperation it is necessary to renew the work of interdepartmental commission on the problems of support of transboundary cooperation, which functions provide analytic, coordinating, informational activity [26] and involvement of the representatives of territorial communities into it. The authors of the article accent this necessity [27].

Ukrainian regions develop international cooperation, demonstrating the bright regional specificity at that. Under conditions of globalization international cooperation of the border territories develops most actively. But it is necessary to note the limitedness of access to the financing within European programs of transboundary cooperation of the Ukrainian regions that are not border ones or situated in the East of the country. Taking into account the State strategy of the regional development, which task is the rise of competitiveness of the regions of Ukraine, the special attention must be paid by such regions to the development of international interregional cooperation for the successful economic integration in European and World space, the diverse instruments of interregional interaction must be used more actively. That is why it is expedient to reformat the Interdepartmental commission on the problems of support of transboundary cooperation into Interdepartmental commission on the problems of international cooperation of the regions.

For the coordination of activity of the state and regional power bodies, local authorities, business and public at the solution of problems of international cooperation in the regions it is necessary to use the potential of Agencies of the regional development that effectively cooperate in EU countries with the local and central authorities as the focus centers of strategic planning and accompaniment of the projects of territories development. Henceforward the regions of Ukraine have a possibility to open the net of agencies of the regional development: Government approved the according decision and confirmed the type statute on the agency of regional development [28]. The approved decision would favor the strengthening of institutional ability of regions as to the attainment of aims of their development.

The raise of effectiveness of international cooperation of regions needs also the specification of functions of the Departments of external economic activity of the regional administrations and agreement of the system of arrangements, offered in the programs of international cooperation with strategic aims, offered in the strategies of economic development of the regions.

That is international cooperation as a direction of activity of regional power needs improvement of mechanism of coordination of relations between the central and regional power bodies and also establishing of communications with business and public of the region. Exactly at the regional level it is necessary to activate the support of potential participants of transboundary project, especially, to favor their awareness about the existent programs of transboundary cooperation. In general informational support is an important organizational factor of development of international cooperation of regions.

The analysis indicates that the possibilities of international cooperation of regions are limited by the obstacles, connected with imperfectness of its institutional, financial, organizational support. All these factors are considerably connected with each other and the absence of their solution 
at the state level puts limitations for intensification of activity at the regional one, impedes the creation of effective mechanisms for coordination of activity of participants of this process. At the same time the regional power bodies have the possibilities and correspondent instruments for its activation.

That is why the solution of problems of intensification of international interaction of regions needs the system approach, which realization is connected with the necessity of institutional formation of authorities, duties, responsibilities of the power bodies of the different levels, elaboration of effective communicative channels and organizational mechanisms of strategic and program-objective management of activity. It is expedient to create the regional program of international cooperation that would determine the competitive advantages, priority branches, possibility and resources of their development with orientation on the strengthening of competitiveness of every region.

\section{Discussion of results}

The possibility of development of intensification of international cooperation of Ukrainian regions due to diversification of its forms and instruments was determined in the article. There were analyzed institutional, financial, organizational factors that limit the full use of international cooperation potential. The results of researches can be used for elaboration of organizational mechanisms of the management of development of international cooperation of regions. The analysis can be considered as such that outline the directions of further, more detailed, study of the factors that limit the cooperation development at both state and regional levels and also for determination of obstacles and prospects in the use of concrete forms of international cooperation by Ukrainian regions.

\section{Conclusions}

As the result of studies:

- the factors of international environment that influence international cooperation of Ukrainian regions were considered and it was revealed, that the possibilities of its intensification are given by the development of new forms of cooperation;

- institutional, financial, organizational factors that impede the full use of international cooperation were determined. It was proved, that the main limitation is organizational factors, especially: absence of coordination between the departments that are responsible at the national level for realization of programs for international cooperation between regions; absence of mechanisms of interaction between the state and regional authorities, public and business representatives; insufficient informational support of concerned parties;

- analysis indicates that the solution of these problems needs the complex approach to organization of interterritorial cooperation and elaboration of transparent mechanisms of coordination and interaction that would combine the efforts of state and regional power bodies, local authorities, business and public in the solution of problems of institutional, organizational, financial support of international cooperation. It is expedient to use the mechanisms of strategic and program-objective management of activity.

\section{References}

[1] Markusen, A. (1987). Regions: Economics and Politics of Territory. New York: Rowman and Littlcfield, 304.

[2] Granberg, A. G. (2000). Osnovy regional'noj ekonomiki. Moscow, 305.

[3] Storper, M. (1997). The Regional World. Territorial Development in a Global Economy. New York - London: The Guilford Press, 338.

[4] Brial, F. (1997). Decentralisation territoriale et cooperation internationale. Paris: l'Harmattan, 395.

[5] Haegi, C. (1995). The Europe of region. Geneve: Georg Editeur SA, 298.

[6] Greenwood, J. (1997). Representing Interests in the European Union. doi: 10.1007/978-1$349-25655-6$

[7] Hueglin, T. O. (1986). Regionalism in Western Europe: Conceptual Problems of a New Political Perspective. Comparative Politics, 18 (4), 439. doi: 10.2307/421693

[8] Makogon, Ju. V., Ljashenko, V. I. (2003). Formy i napravlenija mezhregional'nogo transgranichnogo sotrudnichestva. Doneck: OOO «Jugo-Vostok, Ltd», 512. 
[9] Byelyenkyj, P. Yu., Mikula, N. A. (2001). Formuvannya ta rozvytok systemy mizhregionalnogo ta transkordonnogo spivrobitnycztva v Ukrayini. Regionalna ekonomika, 3, 61-74.

[10] Mikula, N. (2004). Mizhterytorialne ta transkordonne spivrobitnycztvo. Lviv: IRD NAN Ukrayiny, 395.

[11] Vlasov, V. G. (2015). Polityka regulyuvannya mizhnarodnyh zv'yazkiv regioniv: zaxidnoyevropejskyj dosvid. Mykolayiv, 231.

[12] Artomov, I. V. (2009). Transkordonne spivrobitnycztvo v yevrointegracijnij strategiyi Ukrayiny. Uzhgorod: Lira, 520.

[13] Kravciv, V. S. (Ed.) (2015). Rozvytok transkordonnogo spivrobitnycztva: naukovo-analitychna dopovid. Lviv, 126. Available at: http://ird.gov.ua/irdp/p20160401.pdf

[14] «Shhodo vykorystannya potencialu mizhregionalnogo mizhnarodnogo spivrobitnycztva u kompleksnomu rozvytku prymorskyh regioniv Ukrayiny» Analitychna zapyska. Available at: http://www.niss. gov.ua/articles/968/

[15] Fljajsher, K., Bensussan, B. (2012). Strategicheskij i konkurentnyj analiz. Metody i sredstva konkurentnogo analiza v biznese. Moscow: BINOM. Laboratorija znanij, 541.

[16] Metodologiya planuvannya regionalnogo rozvytku v Ukrayini. Instrument dlya rozrobky strategij regionalnogo rozvytku i planiv yih realizaciyi. Proekt Yevropejskogo Soyuzu Pidtrymka polityky regionalnogo rozvytku. Available at: http://rozvytok.in.ua/library/download/file?fid=25.893

[17] Monastyrnyj V. M. (2013). Shlyahy vdoskonalennya derzhavnogo regulyuvannya mizhregionalnogo spivrobitnycztva. Aktualni problemy derzhavnogo upravlinnya, 2, 97-104.

[18] Evropejskaja ramochnaja konvencija o prigranichnom sotrudnichestve territorial'nyh soobshhestv i vlastej (1980). Available at: http://conventions.coe.int/Treaty/rus/Treaties/Html/106.htm.67

[19] Protocol No. 2 to the European Outline Convention on Transfrontier Co-operation between Territorial Communities or Authorities concerning interterritorial co-operation (1998). Available at: http:// www.coe.int/en/web/conventions/full-list/-/conventions/treaty/169

[20] Zakon Ukrayiny «Pro transkordonne spivrobitnycztvo». (2004). Available at: http://zakon3.rada. gov.ua/laws/show/1861-15

[21] Regulation (EC) No 1082/2006 of the European Parliament and of the Council (2006). European grouping of territorial cooperation (EGTC). Available at: http://cor.europa.eu/en/activities/networks/Documents/EN.pdf

[22] Regionalne spivrobitnycztvo mizh Ukrayinoyu ta YeS. Available at: http://mfa.gov.ua/ua/aboutukraine/european-integration/eu-regional-cooperation

[23] Pro zatverdzhennya Derzhavnoyi programy rozvytku transkordonnogo spivrobitnycztva na 2011-2015 roky. Available at: http://zakon5.rada.gov.ua/laws/show/1088-2010-\%D0\%BF

[24] Ekonomika regioniv u 2015 roci: novi realiyi i mozhlyvosti v umovax zapochatkovanyh reform. (2015). Kyiv: NISD, 92. Available at: http://www.niss.gov.ua/public/File/2015_nauk_an_rozrobku/ekon_reg.pdf

[25] LIGABiznesInform. Fond regional'nogo razvitija nedopoluchit bolee $2 \mathrm{mlrd}$ grn. Available at: http://biz.liga.net/print/ekonomika/all/novosti/3225009-fond-regionalnogo-razvitiya-nedopoluchit-bolee-2-mlrd-grn.htm

[26] Polozhennya pro Mizhvidomchu komisiyu z pytan pidtrymky transkordonnogo spivrobitnycztva. Available at: http://zakon1.rada.gov.ua/laws/show/1088-2010-\%D0\%BF/page2

[27] Bila, S. O., Babecz, I. G. Valyushko, I. V., Zhalilo, Ya. A. et al. (2011). Mizhregionalne spivrobitnycztvo u systemi novoyi regionalnoyi polityky Ukrayiny. Kyiv: NISD, 32. Available at: http://www.niss.gov.ua/ articles/608/

[28] Pro zatverdzhennya Typovogo polozhennya pro agenciyu regionalnogo rozvytku (2016). Available at: http://www.kmu.gov.ua/control/uk/cardnpd?docid=248941325 